\title{
History and Philosophy of Geography II: rediscovering individuals, fostering interdisciplinarity and renegotiating the 'margins'
}

\section{Federico Ferretti}

federico.ferretti@ucd.ie

\begin{abstract}
Publications in the field of history and philosophy of geography have shown increasing vibrancy and consistent alignments around some key foci. These are, first, a renewed engagement with biographies and auto-biographies, which is part of wider rediscoveries of individuals as concrete actors in the construction of knowledge. Second, a draw towards interdisciplinarity in reassessing practices such as exploration, mapping and publishing, in connection with broader trends in intellectual history. Third, a continuing interest in topics coming from the 'margins' of mainstream Anglophone scholarship.
\end{abstract}

Keywords: (Auto)Biography; Interdisciplinarity; Intellectual History; Peripheries; Global South

This strange year (2020) has been characterised by the postponement of all face to face conferences, including some key international venues for historians of geography, such as the $35^{\text {th }}$ anniversary of the History and Philosophy of Geography Research Group of the RGS$\mathrm{IBG}^{1}$ and the IGU Conference on heritage geographies, co-organised by the Commission History of Geography. ${ }^{2}$ But is hasn't stopped us publishing or reading. Scholarship in this field of study continued apace, confirming Michiel Van Meeteren's and James D. Sidaway's characterisation of the history of geography as 'an increasingly vibrant' (Van Meeteren and Sidaway 2020, 37) field.

These authors emphasise the emergence of new paradigms that parallel intellectual innovations in cognate disciplines such as the history of science, especially around the adoption of contextual and spatial-sensitive approaches. An outstanding reaffirmation of this principle is

\footnotetext{
${ }^{1}$ See Group's website: https://hpgrg.org.uk/

${ }^{2}$ See Commission's website: https://ugihg.hypotheses.org/
}

F. Ferretti, 2021, "History and Philosophy of Geography II: rediscovering individuals, fostering interdisciplinary and negotiating the margins", Progress in Human Geography, https://journals.sagepub.com/doi/full/10.1177/0309132520973750 [pre-print author's version] 
taking place under the form of scholars' engagement with individuals, mainly through biographies and autobiographies, which are considered as a key tool for challenging disembodied and internalist readings of Geography's histories. In addition to this trend, two tendencies that were discussed in my first report are continuing in heterogeneous forms. These are the continuing commitment of Geography's historians to interdisciplinary approaches to archives and intellectual history, and the rise of the Global South, so too non-Anglophone scholarly circuits, in current conversations around Geography's theories and histories.

\section{The importance of 'actors' and of their (auto)biographies}

The relevance of biography for the history of geography has been noted several times, including in this journal (Keighren 2017). Yet, a new wave of interest for biographical and autobiographical accounts, based on both oral history and archives, is refreshing the pioneering endeavours of scholars like Anne Buttimer, such as the International Dialogue Project (IDP) and the series Geographers Biobibliographical Studies (GBS) (Baigent and Novaes 2019; Ferretti 2020c). Here, I would argue that rediscovering individuals' roles allows for a deeper understanding of Geography's plurality and complexity, making room for considering creativity, originality and dissidence beyond the limitations of readings which are based on 'normal' trends and statistics for broad geographical 'schools', taking the risk of generalisation.

Relevant publications followed two 2019 RGS-IBG sessions, eventually the biographical keynote speech dedicated to the '60 Years in Geography' of Norwegian scholar Arild HoltJensen, convened by Van Meeteren and Heike Jöns, and the session on Ron Johnston's and Peter Taylor's works seen through their authors' recollections, convened by Colin Flint, Sidaway and Van Meeteren. In his introduction to the related special issue of the Norsk Geografisk Tidsskrift, Holt-Jensen defines autobiography 'as a means to improve our disciplinary understanding' (Holt-Jensen 2019, 229), showing assemblages and inside stories and complicating narratives that only deal with disembodied histories of ideas. Van Meeteren situates the genealogy of this endeavour within the intellectual legacy of the IDP, that he defines as an attempt 'to entice this generation of geographers to drop their veil of objectivity and reflect on their life's projects' (Van Meeteren 2019, 252), arguing that Holt-Jensen's recollections can play a similar pedagogical role for later generations of geographers.

F. Ferretti, 2021, "History and Philosophy of Geography II: rediscovering individuals, fostering interdisciplinary and negotiating the margins", Progress in Human Geography, https://journals.sagepub.com/doi/full/10.1177/0309132520973750 [pre-print author's version] 
In the same journal issue, Ron Johnston (now sadly deceased - see below) reflected on his own autobiography and on the openings that working on available protagonists' recollections can provide to disciplinary histories. He also argued that personal memories correct the limitations of sources such as written papers and official records, because 'even a small episode in disciplinary history' (Johnston 2019, 246) can unveil matters that would otherwise remain obscure. Likewise, a paper commenting the session on Johnston's and Taylor's books includes reflexions on the authors' trajectories, to put an emphasis on "“authorial voices" often lacking in accounts of the history of geography' (Sidaway, Van Meeteren and Flint 2020, 2). This implies renewed methodological reflections on the need for returning materiality and corporeality to the history of ideas, by focusing on experiences of the real people who constructed these ideas.

It is no coincidence that, in the new edition of the International Encyclopaedia of Human Geography, an entry on 'Oral History', authored by Mark Boyle, tries to set an 'oral history agenda' for geographers. Boyle argues that life histories 'enliven historical geographical research' (Boyle, 2020, 7). While performing 'history from below' (Boyle, 2020, 8), oral history especially reveals current trends in the discipline, stressing importance of social and political uses of history, which is never innocent or neutral. A powerful example of the mobilisation of oral histories which speak boldly to present-day issues is David Simon's (2019) book on the Holocaust escapees. A critical development geographer, Simon drew an interest for the victims of the Holocaust from his own family history and noted that some key development thinkers of the twentieth century were escapees or children of Holocaust victims.

Carrying out this research, Simon discovered that the development scholars who had such personal or family stories were much more than what he imagined and finally 'conducted some 33 interviews, including with spouses and children of deceased survivors/escapees on several continents' (Simon 2019, 2). While oral memories of the Holocaust are a rich field of investigation, one that critical scholars consider essential to fight against negationism and neofascisms associated with current waves of xenophobic and racist sovereignism (not extraneous to Anti-Semitism), what appears relevant in the recollections discussed by Simon is the

F. Ferretti, 2021, "History and Philosophy of Geography II: rediscovering individuals, fostering interdisciplinary and negotiating the margins", Progress in Human Geography, https://journals.sagepub.com/doi/full/10.1177/0309132520973750 [pre-print author's version] 
application of this method to scholars' biographies. While most of these development scholars were not fully-fledged geographers, their intellectual engagement was often akin to geographical themes: Simon shows how scholars' life stories matter to current challenges, in Geography and cognate disciplines.

Alongside autobiography and oral history, biography based on documents and archives remains a largely practiced genre in Geography. An amazing case is the current issue of $G B S$, which is entirely dedicated to geographers' biographies which are authored by Hugh Clout (eventually of David Lowenthal, Eric Herbert Brown, Maurice Le Lannou, Renée Rochefort, Gaston and Jean-François Gravier, Pierre and Myriem Foncin). The introduction of the editors Elizabeth Baigent and André Reyes Novaes contains a meta-biographic tribute to Clout, whose incredible work is a pillar of this series, which tries 'not just rounding up the usual suspects' by 'memorialising the forgotten' (Baigent and Novaes 2020). Clout also understands biography as a means to give an afterlife to the intellectual legacy of biographed people, as it is shown by his endeavours, with Michael Jones, to publish pieces of work on the history of geography by Bill Mead (Mead 2020), who was also one of the earliest interviewees of the IDP.

In Baigent and Novaes's text Clout, who published an impressive list of 51 biographies in $G B S$ and other 59 biography-related texts on different supports, is the biographer but also the biographed geographer. This reveals an important feature of biographies: they can talk of lives and places of their authors as well as of those of the people who are their 'objects'. It is worth adding that the $G B S$ 's editors are committed to counter traditional Euro-centric and patriarchal approaches to the discipline, for instance dedicating the 2019 issue entirely to women (Baigent and Novaes 2019) and the forthcoming 2021 one to geographers from the Global South.

Biographical work continues addressing relatively traditional written records including travel diaries (Ferretti 2020c) and personal archives such as Edward A. Ackerman's papers. These were recently studied by Elvin Wyly, who argues for rediscovering the role that Ackerman played in the early stages of the so-called quantitative revolution in Geography (Wyly 2019). Matters on quantitative and 'applied' geography are likewise explored by Van Meeteren in his work on Dutch geography in the 1930s-1960s, paying special attention to careers, networks

F. Ferretti, 2021, "History and Philosophy of Geography II: rediscovering individuals, fostering interdisciplinary and negotiating the margins", Progress in Human Geography, https://journals.sagepub.com/doi/full/10.1177/0309132520973750 [pre-print author's version] 
and social (including family) relations among individual scholars in shaping the notion of polycentric urban region (Van Meeteren 2020). In the French journal Cybergeo, the current interest for early protagonists in quantitative geography is confirmed by a paper of Anne Radeff, analysing the Chinese reception of Walter Christaller's works. According to Radeff, more than one thousand scholarly papers have quoted the German urbanist since the first Chinese translations of his texts in the 1960s-1970s. Crucially, the controversial biography of Christaller, who had been a collaborator of the Nazi regime, was a matter of concern for Chinese authorities, which further demonstrates that ideas cannot be separated by the concrete lives of those who elaborate them. Radeff ironically notes how Christaller's thinking especially fitted authoritarian regimes, eventually Nazism and Chinese Communism (Radeff 2020).

Autobiography also underpins contributions such as a paper where Canadian geographer Olav Slaymaker recollects his professional story in relation to his 50 -year-long participation to IGU conferences, stressing the importance of his relations with certain individuals to understand what went on behind the scenes in different countries, including those of the Eastern Bloc (Slaymaker 2019). In a special issue of the Scottish Geographical Journal dedicated to the centenary of the Geography Department at the University of Aberdeen, Keith Chapman and Alastair M.D. Gemmell define their own written recollections of long-serving department members as 'unreliable memoirs', not without some irony. In fact, these memories are doubtlessly one of the most revealing pieces of the issue, beyond what the authors define as the "rigour and objectivity and the "official history". While they deem their recollections 'selective, impressionistic and, perhaps, distorted through the lens of our respective roles and responsibilities during our working lives in the Department' (Chapman and Gemmell 2019, 219), I would content that this is exactly the point that qualifies individuals' memories as tools to emphasize people's experiences, relations and material concerns, beyond big Theories.

Furthermore, the special issue's editors confirm the importance of places and contextual approaches to the production of knowledge (Philip and Edwards 2019). Alongside papers which are based on traditional archival records, they publish posthumous recollections of former Vice-Principal, geographer Kenneth Walton, accounting for the impact, in the 1970s, of the Department's move: 'Straight to the C.B.D. of Old Aberdeen with its chemist, fish-

F. Ferretti, 2021, "History and Philosophy of Geography II: rediscovering individuals, fostering interdisciplinary and negotiating the margins", Progress in Human Geography, https://journals.sagepub.com/doi/full/10.1177/0309132520973750 [pre-print author's version] 
shop/greengrocer, bakery, licensed grocer, newsagent, corner shop, pub, public convenience and the telephone box which was ... monopolised by a tired little bookie's runner whose stance was against the wall on the forecourt of St. Mary's' (Walton 2019, 217).

Finally, a focus on individual trajectories helps to better understand dissidences, prickliness and queerness within or outside a scholarly community, beyond what is standard, normal and conforming to the norm. This also emerges in Gerry Kearns's remarks on the novel 'Transit' by Jewish-German socialist writer Anna Seghers (1900-1983), whose biography, marked by marginalisation, political persecution and end exile, still speaks to geographers who are interested in placelessness (Kearns 2019, 1).

\section{Ron Johnston (1941-2020)}

I cannot mention the role of individuals in both charting and affecting the evolution of Geography without making special mention of Ron Johnston (1941-2020), whose trajectory outstandingly exposes how effective an individual's role can be in influencing diverse parts of a discipline. Johnston's personal contribution to the history of geography further highlights Geography's variety and diversity, and the need for pluralism in considering its different voices. In the early stages of his career, 'Ron looked for spatial order in the often messy social landscape' (Castree 2020, 2) becoming a leading figure in 'spatial science', although he had surely developed sensitivity for different approaches, having been supervised by Walter Freeman, another of the IDP interviewees and a co-founder of GBS. Johnston's 1979 Geography and Geographers: Anglo-American Human Geography since 1945 was a history of geography that gave voice to plural stances in a period when geographers were disputing 'which pair of glasses-positivist, radical or humanistic-needed to be worn to comprehend societal shifts' (Sidaway, Van Meeteren and Flint 2020, 3). This may explain the extraordinary longevity of this book as confirmed by its numerous new editions, and the fortune of products such as the Dictionary of Human Geography that Johnston first co-edited in 1981. A progressive and socially committed scholar, provided with manifold talent, Johnston was 'a leading figure in urban geography, in political geography, in the history and philosophy of Geography, and in quantitative research Methods' (Castree 2020, 4). Yet, he was also someone

F. Ferretti, 2021, "History and Philosophy of Geography II: rediscovering individuals, fostering interdisciplinary and negotiating the margins", Progress in Human Geography, https://journals.sagepub.com/doi/full/10.1177/0309132520973750 [pre-print author's version] 
who remained humble enough, until his late days, to claim awareness that we are always writing 'a history, but certainly not the history' (Johnston 2019, 246) of Geography.

\section{Interdisciplinary approaches between exploration, Anthropocene and intellectual history}

As already discussed (Ferretti 2020a), considering history and philosophy of geography as a way to address plural approaches to geographical knowledges and practices allows understanding the richness, complexity and relevance of Geography. It is always an agreeable surprise to find a paper advocating major roles for geographers in wider conversations on notions of Anthropocene, based on what we call 'the geographical tradition'. It was the case with a work of Thomas Barclay Larsen and John Harrington Jr., arguing provocatively that notions of Anthropocene 'build on insights posed by geographers of the eighteenth and early nineteenth centuries: unity of nature, humans as nature made conscious, humans as nature's conscience' (Larsen and Harrington 2020, 1). The authors quote examples of early geographers such as Reclus, Kropotkin and Humboldt (among others) who 'have been studying aspects of the so-called Anthropocene long before the idea's rebirth at the turn of the new millennium' (Larsen and Harrington 2020, 2). Crucially, Larsen and Harrington challenge the adoption of 'very short issue-attention cycle[s, where] an inattentive public ... appear to zigzag from issue to issue' (Larsen and Harrington 2020, 2), dismissing 'old' ideas and cultivating what historians of Geography call the pretention of having invented everything. Their suggestion 'to identify cross-cutting ideas that join diverse human-environment research' (Larsen and Harrington $2020,8)$ chimes with works of other historically minded geographers such as Kearns, and David Nally, discussing cases in the geo-history of human and plant assemblages (Nally and Kearns 2020).

Productive intersections between the history of geography and the wider field of intellectual history, and more specifically the 'history of ideas', have been theorised by Mette Bruinsma, who argues for a rediscovery of Arthur Lovejoy's notion of 'unit-ideas' as a device to foster an 'idealistic history of geography' which remains cognisant of the contextual and situated nature of knowledge, drawing 'connections between the history of ideas and plural non-elitist notions of knowledge' (Bruinsma 2020, 8). In another paper, Bruinsma provides an empirical example of approaches to ideas that do not neglect their materiality, through an investigation

F. Ferretti, 2021, "History and Philosophy of Geography II: rediscovering individuals, fostering interdisciplinary and negotiating the margins", Progress in Human Geography, https://journals.sagepub.com/doi/full/10.1177/0309132520973750 [pre-print author's version] 
of the concepts which circulated in the last 70 years or so at the Geography Department in Glasgow, based on undergraduate dissertations (Bruinsma 2020b).

Critical studies in exploration are a key point in the connection between the history of geography and the wider field of the history of sciences. Scholars such as Peter Martin and Edward Armston-Sheret are powerfully arguing for reconsidering scope and relevance of the renewed field of exploration studies through an 'interdisciplinary focus' (Martin and ArmstonSheret 2020, 2). They especially address practices of exploration that are revealed by critical archival research, drawing upon a plurality of approaches to 'broader historical processes, including race, class, gender, practices of knowledge production and circulation, as well as empire and colonialism' (Martin and Armston-Sheret 2020,9). Exploration can also shed light on wider societal issues addressed by social and cultural history, such as the relation between Victorian society and the problem of alcohol consumption versus 'temperance' (ArmstonSheret 2019).

Analysing archives of Artic expeditions by Danish explorer Enjar Mikkelsen, Martin warns against critiques of the imperial role of exploration that may remain Eurocentric as far as they neglect 'the significant role that indigenous people have played in the exploration' (Martin 2020, 24). For Martin, exploration should be considered as a complex and negotiated process, which was variously carried out, reported, published and archived. Matters on credibility also emerge in the efforts that Mikkelsen made 'to persuade the [RGS] fellows that indigenous knowledge ought to be considered trustworthy and reliable' (Martin 2020, 34). Similar issues about authorisation and the silencing of indigenous knowledge are addressed by Johanna Skurnik, analysing controversies around colonial maps published by nineteenth-century London mapmaker and publisher John Arrowsmith. While Arrowsmith was very respected and his endorsement constituted a source of authority for explorers' and mapmakers' products, diverging views on an Australian map by traveller George Grey exposed the complex mechanisms of construction (or destruction) of someone's trustworthiness that Skurnik defines a 'credit economy' (Skurnik 2019, 8), demonstrating again that indigenous knowledge was formally despised but actually exploited at several levels.

F. Ferretti, 2021, "History and Philosophy of Geography II: rediscovering individuals, fostering interdisciplinary and negotiating the margins", Progress in Human Geography, https://journals.sagepub.com/doi/full/10.1177/0309132520973750 [pre-print author's version] 
The history of geography contributes to broader histories of science in a range of works including a chapter of Simon Naylor and Matthew Goodman on historical geographies of colonial atmospheric observatories (Naylor and Goodman 2020), and an International Encyclopaedia entry by Charles Withers on Enlightenment Geography. Withers inserts the production of geographical knowledge in the context of a transnational intellectual traffic of ideas' (Withers 2020,139), which constitutes one of the more remarkable features of this period in intellectual history. At that moment, although Geography was not yet an established academic discipline in the sense that we give to this definition today, Withers notes how several publications tried to 'emphasize geography as a coherent body of knowledge about a clearly defined object, namely the situation of places on the earth and the content of those places in human and natural terms' (Withers 2020, 146). Interdisciplinarity is highlighted, literally, in a case discussed by Emily Hayes, that is Halford Mackinder's admiration for John Tyndall's physics, stressing their common interest in' light-conducting educational instruments' (Hayes $2020,570)$ such as the magic lantern. Hayes concludes that the works of both men were too complex and multifaceted to 'be equated with those of a single discipline' (Hayes 2020, 593).

In the field of visual studies applied to the production of geographical knowledge, Felix Driver investigates the role of travellers' drawings in constructing views of extra-European peoples, through the analysis of an exceptional archival document, namely the travel albums of British naval surgeon Linton Palmer. Driver highlights the variety of these documents' uses, confirming the need of adopting transdisciplinary tools in the study of the "performative nature of visual documentation' (Driver 2020,12). While this section discussed the methodological and disciplinary variety of historiographical approaches to Geography, the next one discusses the diversity of this field of study as for some outputs which lie at the margins of the dominant linguistic, epistemological and political disciplinary canons.

\section{Negotiating the margins}

As noted in my previous report (Ferretti 2020a), a growing interest characterises contributions coming from the Global South, or from actors other than the classical white, male and middleclass Anglophone academic. This complements a burgeoning scholarship addressing historical experiences of anti-colonialism and decolonisation (Davies 2020; Clayton 2020), and of

F. Ferretti, 2021, "History and Philosophy of Geography II: rediscovering individuals, fostering interdisciplinary and negotiating the margins", Progress in Human Geography, https://journals.sagepub.com/doi/full/10.1177/0309132520973750 [pre-print author's version] 
radicalism and internationalism in global perspective (Featherstone, Copsey and Brasken 2020; Hodder, Heffernan and Legg 2020). An area which attracts special interest is Latin America, as the latest works on Brazilian critical geographies show (Ferretti 2020b and 2020d). A report by Daniel Paiva and Francisco Roque de Oliveira tries for the first time to draft a compared history of Brazilian and Portuguese geography in the twentieth century, considering both as 'semiperipheral' (Paiva and Roque de Oliveira 2020,2) communities associated by transnational links. Yet, their relationship was always asymmetric, due historically to Brazil's colonial condition and, currently, to the numeric disproportion in the number of universities and scholarly outputs in favour of Brazil. For the authors: 'Brazil was never under the influence of Portuguese geography, but the North-South gaze was also never inverted' (Paiva and Roque de Oliveira 2020,13). However, their paper confirms the pluralism of geographical traditions and the increasing scholars' appetite for exploring cases beyond the Anglosphere (Ferretti 2020a).

Several works address cases from Brazil and Latin America, including a paper by Christiane Fabíola Momm and Heike Jöns on the national conferences of Brazilian planners from 2004 to 2013, taken as an example in the investigation of conference spaces as key contexts for the shaping of knowledges and related networks (Momm and Jöns 2020). In a collective book edited by the IGU Commission History of Geography on Decolonising and Internationalising Geography (Schelhaas et al. 2020), some chapters extend this line of investigation on 'other geographical traditions'. It is the case with Verónica Ibarra García’s and Edgar Talledos Sanchez's chapter discussing the figures of Josué de Castro and António Nuñez Jimenez as forerunners of Latin American critical geographies (Ibarra Garcia and Telledos Sanchez 2020), with André Reyes Novaes's text on the approaches to indigenous maps of historian Jaime Cortesão as an early acknowledgement of indigenous territorial knowledges (Reyes Novaes 2020), and with Mariana Lamego's chapter, questioning matters on dominant languages and authorised scholarly communication around the 1956 International Geographical Congress celebrated in Rio de Janeiro. Traditionally considered as a watershed in the history of Brazilian geography, this congress was also one of the last that worked as an effective multilingual assembly, and the only one that took place in South America (Lamego 2020). In the same book,

F. Ferretti, 2021, "History and Philosophy of Geography II: rediscovering individuals, fostering interdisciplinary and negotiating the margins", Progress in Human Geography, https://journals.sagepub.com/doi/full/10.1177/0309132520973750 [pre-print author's version] 
other authors address examples outside the 'core' such as Akio Onjo discussing the experience of blessed war veteran in Japanese national imaginations (Onjo 2020).

Scholarship on early women's agency in traditionally masculine geographical tasks such as exploration and mapmaking contributes to current calls for enlarging the field of the history of geography to protagonists who had been neglected until recent times. A blog text by ArmstonSheret and Keighren comments a frontispiece portrait of explorer Isabella Bird noticing that: 'Dress was an important issue for women travellers in the nineteenth century ... How a woman chose to dress while travelling overseas could make or break her reputation' (Armston-Sheret and Keighren 2020). A paper by Phil Dodds contributes to a 'feminist historiography of geography' by examining female networks of bookselling and reading in Enlightenment Edinburgh, claiming that women were protagonists rather than mere 'enablers' (Dodds 2020, 270) of Scottish Enlightenment. This reveals an early taste for geography in domestic spaces, but also in 'institutions where women supervised the geographical learning of women, using diverse texts that imply a degree of scientific interest in geography' (Dodds 2020, 279). A similarly neglected case of female agency is the story of Martha Bielenstein: Catherine Gibson shows that Martha, the daughter of famous Latvian scholar August Bielenstein, played a fundamental role in realising the atlases which accompanied her father's studies. Although overshadowed by August's authoritarian figure, Martha's work was a case in the more general 'involvement of women in cartography in the home and print workshops' (Gibson 2020, 1) in the intellectual and editorial context of Imperial Russia, which still deserves rediscovery.

If we consider what happens outside the world of Anglophone publications, we find an interest for Iberian worlds, including Latin America, in a research project on the construction of borders during the eighteenth and nineteenth centuries that was carried out at the University Carlos III in Madrid. Contributed by an international and multilingual team of specialists in the history of geography and cartography, the project Trazar la linea (Drawing the Line) led to the organisation of a series of conferences plus publications such as a special number of Spanish journal Revista de historiografía. In the Introduction, the project leader Jacobo García-Álvarez explains the relevance of studying international treaties to understand key factors in the creation of modern territorial states, such as 'a notion of sovereignty in territorial and exclusive terms'

F. Ferretti, 2021, "History and Philosophy of Geography II: rediscovering individuals, fostering interdisciplinary and negotiating the margins", Progress in Human Geography, https://journals.sagepub.com/doi/full/10.1177/0309132520973750 [pre-print author's version] 
and 'frontiers of a linear type' (Garcia-Álvarez 2019, 10). While maps remain one of the main sources to understand early diplomatic agreements which defined the external shapes of modern states (Garcia-Álvarez and Puyo, 2019), new consideration is given to the mobilisation of imperial legacies in the construction of borders and national imaginations (such as the 'Island-Brazil') of decolonised South-American states in the nineteenth century, including the use of indigenous knowledge (Lois 2019; Zusman and Nunes 2019).

Scholarship in Spanish and Portuguese from Latin America is continuing to reappropriate critically histories of geography through the translation of 'classical' authors whose texts are analysed to discuss political uses of the past (Ribeiro 2019) or to find insights for writing histories of geography adopting cultural perspectives (Pedrosa and Seemann 2020). This includes the continuing rediscovery of critical traditions within Brazilian geography (Ribeiro jr 2020; Hatch and Talledos 2020). In the principal South-American journal dedicated to the history of geography, Terra Brasilis, Rafael Augusto Andrade Gomes summarises these tendencies outlining the need for writing plural disciplinary histories which are cognizant of Latin-American specificities, drawing upon the idea of a 'mestizo geography' as discussed by Amália Inés Geraiges de Lemos (Gomes 2019; Lemos 2018).

In other traditions that might be defined as 'peripheral' or 'semiperipheral', such as Italian geography, the rediscovery of critical traditions is likewise ongoing. It is the case with a recent special issue of the Rivista Geografica Italiana reassessing the legacy of Antonio Gramsci in a geographical perspective. Significantly, the promoters of this debate highlight how astonishing has been the substantial absence of references to Gramsci in Italian geography so far (Dini 2019; Zilli 2019), partially due to the political and epistemological conservatism that has characterised most of Italian geography until recent times. Yet, some contributors show how Gramscian legacies can be mobilised to understand the 'Southern Question' in today's Italy, challenging nationalistic populisms (Rossi 2019). They suggest spatial readings of Gramsci's thinking in twentieth-century Italian society (Agnew 2019) and in critical urban geographies (Petsimeris 2019).

\section{Conclusion}

F. Ferretti, 2021, "History and Philosophy of Geography II: rediscovering individuals, fostering interdisciplinary and negotiating the margins", Progress in Human Geography, https://journals.sagepub.com/doi/full/10.1177/0309132520973750 [pre-print author's version] 
Again, the field of history and philosophy of geography is showing vibrancy in relation to wider debates within Geography and to the broader context of social sciences. Importantly, all the strands that I have highlighted in this report are connected with critical studies. This is first the case with the current foci on biography and autobiography, which extend former discussions on the need for contextual and spatial-sensitive approaches giving some materiality to theory and allowing scholars to grasp originality, unorthodoxy and dissidence in a field like geography which has always been far from homogeneous.

This is also the case with interdisciplinary approaches to geographical practices in the history of sciences, given that these fields of study are increasingly linked with postcolonial approaches and critical reassessments of the discipline's pasts. It is finally the case with the continuing rediscovery of radical traditions and of different protagonists such as non-academic geographers and early women in geography. This includes growing interest for non-European and non-Anglophone geographical traditions, in which other critical reassessments of disciplinary histories are ongoing, and the 'margins' of mainstream Northern scholarship are constantly renegotiated.

\section{References}

Agnew J (2019) Low Geopolitics and 'realtà effettuale'. Rivista geografica italiana, CXXVI(4):198-203.

Armston-Sheret E (2019) “A good Advertisement for teetotallers": Polar explorers and debates over the health effects of alcohol, 1875-1904. The Social History of Alcohol and Drugs 33(2): 257-285.

Armston-Sheret E and Keighren IM (2020) Fashioning the frontispiece: The role of clothing in the travel narratives of Isabella Bird. Adam Matthew a SAGE Publishing Company, https://www.amdigital.co.uk/about/blog/item/clothing-in-the-travel-narratives-of-isabellabird

Baigent E and Novaes A (2019) Editorial. Geographers, Biobibliographical Studies 38: 1-13. Baigent E and Novaes A (2020) Not just rounding up the usual suspects: Hugh Clout and geography's stories. Geographers, Biobibliographical Studies 39 [forthcoming].

Boyle M (2020) Oral history. International Encyclopedia of Human Geography 10:7-11.

F. Ferretti, 2021, "History and Philosophy of Geography II: rediscovering individuals, fostering interdisciplinary and negotiating the margins", Progress in Human Geography, https://journals.sagepub.com/doi/full/10.1177/0309132520973750 [pre-print author's version] 
Bruinsma M (2020a) Revisiting the history of ideas: A forgotten resource for historians of geography Geography Compass e12535.

Bruinsma M (2020b) The geographers in the cupboard: Narrating the history of Geography using undergraduate dissertations Area https://doi.org/10.1111/area.12653

Castree N (2020) A tribute to Ron Johnston (30 March 1941-29 May 2020). Progress in Human Geography early view: https://journals.sagepub.com/doi/full/10.1177/0309132520938254

Chapman K and Gemmell AMD (2019) 'Unreliable memoirs': geography at Aberdeen 19602002 Scottish Geographical Journal 135(3-4):219-235,

Clayton D (2020) The passing of 'Geography's Empire' and question of geography in decolonization, 1945-1980. Annals of the American Association of Geographers, early view https://doi.org/10.1080/24694452.2020.1715194

Davies A (2019). Geographies of Anticolonialism: Political Networks Across and Beyond South India, c. 1900-1930. London, RGS-IBG Books.

Dini F (2019) Le ragioni di una discussione destinata a Gramsci. Rivista geografica italiana, CXXVI(4):193-197.

Dodds P (2020) Geographies of the book(shop): Reading women's geographies in Enlightenment Edinburgh. Transactions of the Institute of British Geographers 45:270-283.

Driver F (2020) Material memories of travel: the albums of a Victorian naval surgeon. Journal of Historical Geography early view: https://doi.org/10.1016/j.jhg.2020.02.006

Featherstone D, Copsey N and Brasken K (eds.) 2020) Anti-Fascism in a Global Perspective: Transnational Networks, Exile Communities, and Radical Internationalism. Abingdon, Routledge.

Ferretti F (2020a) History and Philosophy of geography I: decolonising the discipline, diversifying archives and historicising radicalism. Progress in Human Geography 44(6):11611171.

Ferretti F (2020b) From the drought to the mud: Rediscovering geopoetics and cultural hybridity from the Global South. cultural geographies 27(4):697-613.

Ferretti F (2020c) Travelling in scholarly lifeworlds: new perspectives on (post)humanism, situated subjectivities and agency from a travel diary. Annals of the American Association of Geographers 110(6):1653-1669.

F. Ferretti, 2021, "History and Philosophy of Geography II: rediscovering individuals, fostering interdisciplinary and negotiating the margins", Progress in Human Geography, https://journals.sagepub.com/doi/full/10.1177/0309132520973750 [pre-print author's version] 
Ferretti F (2020d) Subaltern connections: Brazilian critical geographies, development and African decolonisation. Third World Quarterly 41(5):822-841.

García-Álvarez J (2019) Introducción. Revista de historiografía 30:10-14.

García-Álvarez J and Puyo JY (2019) Los primeros intentos de delimitación moderna de la frontera pirenaica: la Comisión franco-española Caro-Ornano y su legado cartográfico (17841792). Revista de historiografía 30:15-44.

Gibson C (2020) Mapmaking in the home and printing house: women and cartography in late imperial Russia. Journal of Historical Geography 67:71-80.

Gomes RAA (2019) Modos de escrever histórias. Terra Brasilis http://journals.openedition.org/terrabrasilis/5583

Hayes E (2019) Fashioned in the light of physics: the scope and methods of Halford Mackinder's geography. BJHS 52(4):569-594.

Hodder J, Heffernan M and Legg, S. (2020). The Archival Geographies of Twentieth-Century Internationalism: Nation, Empire and Race. Journal of Historical Geography [forthcoming].

Holt-Jensen A (2019) Transformations in the discipline of geography experienced over 60 years by a Norwegian geographer, Norsk Geografisk Tidsskrift - Norwegian Journal of Geography 73(4):229-244.

Ibarra MV and Sánchez ET (2019). Pioneers in Latin American critical geographies, Josué de Castro and Antonio Nuñez-Jimenez. In Schelhaas B, Ferretti F, Novaes A and Schmidt di Friedberg M (eds.). Decolonising and Internationalising Geography: Essays in the History of Contested Science. Berlin: Springer, pp. 17-26.

Johnston R (2019) On (auto)biography and the history of geography. Norsk Geografisk Tidsskrift - Norwegian Journal of Geography 73(4):245-250.

Kearns G (2019) In Transit: Placelessness and the absurd in the writings of Anna Seghers. GeoHumanities 6(1):1-24.

Keighren IM (2017) History and philosophy of geography I: The slow, the turbulent, and the dissenting. Progress in Human Geography 41(5):638-347.

Kuri GH and Sanchez ET (2020) Una mirada a la geografía política brasileña: conversación con el geógrafo Wagner Costa Ribeiro. Investigaciones Geográficas 102: dx.doi.org/10.14350/rig.60199

F. Ferretti, 2021, "History and Philosophy of Geography II: rediscovering individuals, fostering interdisciplinary and negotiating the margins", Progress in Human Geography, https://journals.sagepub.com/doi/full/10.1177/0309132520973750 [pre-print author's version] 
Lamego M (2020) How international was the international Geographical congress in Rio de Janeiro in 1956? On location and language politics. In Schelhaas B, Ferretti F, Novaes A and Schmidt di Friedberg M (eds.). Decolonising and Internationalising Geography: Essays in the History of Contested Science. Berlin: Springer, pp. 113-126.

Larsen TB and Harrington J (2020): Geographic thought and the Anthropocene: What geographers have said and have to say. Annals of the American Association of Geographers early view https://doi.org/10.1080/24694452.2020.1796575

Lemos AIG (2018) Em busca de uma Geografia Latino-Americana Crítica ou por uma Geografia Mestiça. Boletim Paulista de Geografia 100:112-129.

Lois C (2019) De las fronteras coloniales del imperio hispánico en América a los límites internacionales entre Estados latinoamericanos independientes: génesis de la imposibilidad de un mapa político de Sudamérica consensuado. Revista de historiografia 30:207-222.

Martin PR (2020). Indigenous tales of the Beaufort Sea: Arctic exploration and the circulation of geographical knowledge. Journal of Historical Geography 67:24-35.

Martin PR and Armston-Sheret E (2020) Off the beaten track? Critical approaches to exploration studies. Geography Compass 14(1):e12476.

Mead WR (2020) Scandinavian cartography 1650-1800. Norsk Geografisk Tidsskrift Norwegian Journal of Geography early virew: https://doi.org/10.1080/00291951.2020.1811756

Momm CF and Jöns H (2020) Decentralized concentration through cyclical events: The geographies of academic conferences in urban and regional development and planning in Brazil, 2004-2013. Geoforum 112:104-117.

Nally D and Kearns G (2020) Vegetative states: Potatoes, affordances, and survival ecologies. Antipode 52(5):1373-1392.

Naylor S. and Goodman M (2020) Atmospheric empire: historical geographies of meteorology at the colonial observatories. In Mahony M. and Randalls S (eds.) Weather, Climate, and the Geographical Imagination: Placing Atmospheric Knowledges. Pittsburgh: University of Pittsburgh Press, pp. 25-42.

Onjo A (2020) After the excitement of war: 'disabled veterans' in modern Japan. In Schelhaas B, Ferretti F, Novaes A and Schmidt di Friedberg M (eds.). Decolonising and

F. Ferretti, 2021, "History and Philosophy of Geography II: rediscovering individuals, fostering interdisciplinary and negotiating the margins", Progress in Human Geography, https://journals.sagepub.com/doi/full/10.1177/0309132520973750 [pre-print author's version] 
Internationalising Geography: Essays in the History of Contested Science. Berlin: Springer, pp. 27-36.

Paiva D and Oliveira FR (2020) Luso-Brazilian geographies? The making of epistemic communities in semi-peripheral academic human geography. Progress in Human Geography, early view: https://doi.org/10.1177/0309132520923062

Pedrosa BV and Seemann J (2020) Carl Sauer, fronteiras e povoamento dos Estados Unidos. GEOgraphia 22(48) https://periodicos.uff.br/geographia/article/view/43102/24531

Petsimeris P (2019) Le 'città del silenzio': alcune riflessioni su Gramsci e la geografia urbana. Rivista geografica italiana CXXVI(4):212-216.

Philip LJ and Edwards KJ (2019) Guest Editorial: Centenary of the Department of Geography, University of Aberdeen. Scottish Geographical Journal 135:3-4.

Radeff A (2019) Walter Christaller traduit en chinois (1998-2010). Cybergeo http://journals.openedition.org/cybergeo/33486

Reyes Novaes A (2020) Mapping cross-cultural exchange, Jaime Cortesão's dialogues and documents on the role of indigenous knowledge in Brazilian exploration. In Schelhaas B, Ferretti F, Novaes A and Schmidt di Friedberg M (eds.). Decolonising and Internationalising Geography: Essays in the History of Contested Science. Berlin: Springer, pp. 1-16.

Ribeiro G (2019) De volta para o futuro. Terra Brasilis http://journals.openedition.org/terrabrasilis/5468

Ribeiro JRS (2020), Uma resposta política para a fome: Josué de Castro e as ligas camponesas, GEOgraphia 22(48): https://periodicos.uff.br/geographia/article/view/34734/24515

Rossi U (2019) Il metodo di Gramsci: ascesa nazional-populista e nuova questione meridionale in Italia. Rivista geografica italiana CXXVI(4):222-227.

Schelhaas B, Ferretti F, Novaes A and Schmidt di Friedberg M (eds.) (2020) Decolonising and Internationalising Geography: Essays in the History of Contested Science. Berlin: Springer.

Sidaway JD, Van Meeteren M and Flint C (2020) Through troubled times: reflections on Ron Johnston's Geography and Geographers: Anglo-American Human Geography since 1945 (1979) and Peter Taylor's Political Geography: World Economy, National-State and Locality (1985). GeoJournal https://doi.org/10.1007/s10708-020-10199-z

Simon D (2019) Holocaust escapees and global development: hidden histories. London: Zed.

F. Ferretti, 2021, "History and Philosophy of Geography II: rediscovering individuals, fostering interdisciplinary and negotiating the margins", Progress in Human Geography, https://journals.sagepub.com/doi/full/10.1177/0309132520973750 [pre-print author's version] 
Skurnik J (2020) Authorizing geographical knowledge: John Arrowsmith, mapmaking and the mid nineteenth-century British Empire. Journal of Historical Geography, early view: https://doi.org/10.1016/j.jhg.2020.04.003

Slaymaker O (2019) In praise of the International Geographical Union. The Canadian Geographer/Le Géographe canadien 63(4):510-519.

Van Meeteren M (2019) The pedagogy of autobiography in the history of geographic thought. Norsk Geografisk Tidsskrift - Norwegian Journal of Geography 73(4):250-255.

Van Meeteren M (2020) A prehistory of the polycentric urban region: excavating Dutch applied geography, 1930-60. Regional Studies, Early view:

https://doi.org/10.1080/00343404.2020.1800629

Van Meeteren M and Sidaway JD (2020) History of geography. In Kobayashi A (Ed.), International Encyclopedia of Human Geography, vol. 7. London: Elsevier, pp. 37-44.

Walton K (2019) Twenty-five years in St. Mary's. Scottish Geographical Journal 135:217218 ,

Withers CWJ (2020) Enlightenment Geography. In Kobayashi A (Ed.), International Encyclopedia of Human Geography, Vol. 4. London: Elsevier, pp. 137-149.

Wyly E (2019) Geography's Quantitative Revolutions: Edward A. Ackerman and the Cold War Origins of Big Data. Morgantown: West Virginia University Press.

Zilli S (2019) Gramsci e la geografia italiana: soltanto una questione di interpretazione? Rivista geografica italiana CXXVI(4):228-231.

Zusman P and Nunes S (2019) Resonancias de los Tratados de Madrid (1750) y San Ildefonso (1777) en las lecturas sobre la formación de territorio de los Estados de Argentina y Brasil. Revista de historiografía 30:191-205.

F. Ferretti, 2021, "History and Philosophy of Geography II: rediscovering individuals, fostering interdisciplinary and negotiating the margins", Progress in Human Geography, https://journals.sagepub.com/doi/full/10.1177/0309132520973750 [pre-print author's version] 